\title{
CONSTITUTIONAL REFORM IN UKRAINE - A MEANS OF IMPROVING THE JUDICIARY
}

DOI:10.47743/rdc-2016-2-0005

\author{
Doctor of Law, Associate Professor Oleksandr ȘCERBANIUK \\ Head of Department of Justice, \\ "Iurii Fedkovici" National University of Cernăuți
}

\section{Summary}

This study reveals recent constitutional developments in Ukraine, notably in the constitutional jurisdiction, emphasizing the strengthening of the Constitutional Court's role, as a key institution that aims at protecting and developing the principles and values of constitutionalism and, thereby, the rule of law.

Keywords: constitutional court; constitutional reform; Venice Commission; direct access to constitutional justice

According to the Constitution of Ukraine, the assertion and safeguarding of an individual's rights and freedoms is the main duty of the State (Article 3). The observance of this obligation is impossible without the existence of an effective mechanism to protect human rights and freedoms in case of violations.

Judicial reform is one of the most anticipated in society as a fair, impartial and unprejudiced trial is an important guarantee for the effective fight against corruption, for the protection of citizens' rights and freedoms and for the establishment of rule of law.

The Strategy for Sustainable Development "Ukraine - 2020", approved by the Decree no. 5 of President of Ukraine on 12 January 2015, the judicial reform has been identified as a priority. As a result, by the Decree no. 276 of President of Ukraine on 20 May 2015, the judicial reform strategy in the years 2015-2020 was approved, which states that the judicial reform will include an update of legislation and the enactment of the amendments to the Constitution of Ukraine. For this purpose it was established the Constitutional Commission in March 2015, which drafted the suggestions to amend the Constitution of Ukraine regarding justice, which, in general, were assessed as favourable by the Venice Commission in its preliminary conclusions ${ }^{1}$. On 23 October 2015, the Venice Commission adopted its final report, which states that "the latest amendments

\footnotetext{
${ }^{1}$ Document CDL-PI (2015) 016 of 24 July 2015.
}

CONSTITUTIONAL JURISDICTIONS 


\section{Oleksandr ŞCERBANIUK}

to the Constitution of Ukraine, drafted by the working group of the Constitutional Commission for Justice are very positive and well prepared and deserve full support"2.

The key objective of the proposed amendments is to improve the constitutional grounds of justice in order to ensure to any individual the right to a fair trial by an independent and impartial court. The means of achieving this aim are strengthening the independence of the judiciary, especially through its depoliticisation, increasing the responsibility of the judiciary before the public, the judiciary renewal etc.

The Bill on the constitutional amendments to justice requires the revision of the duties granted to the Verkhovna Rada of Ukraine and to the President of Ukraine in justice, in accordance with the international standards. Thus, the constitutional powers of the Verkhovna Rada of Ukraine on the permanent appointment procedure of judges will be transferred to a new body - the Supreme Council of Justice.

In order to ensure the security of tenure of judges as one of the guarantees of their independence, the concept of "appointment of judges for the first time" ${ }^{3}$ shall be cancelled and the appointment as judge shall have permanent character. The above is not applicable to the judges of the Constitutional Court of Ukraine, who are appointed for a nine-year term of office.

Significant changes are planned for the status of judges, including: increasing the retirement age threshold and professional qualifications for the candidates who run for the office of judge, introducing the principle of competitive appointment as judges, to clarify and strengthen the guarantees of independence and immunity of judges. Thus, any citizen of Ukraine may be judge, not younger than thirty years old and not older than sixty-five years old, who has a law degree and professional experience in the field of law for at least five years. She/he shall be competent, virtuous and speak the state language.

Amendments to the Constitution introduce the concept of functional immunity of a judge. The current Constitution of Ukraine establishes the absolute immunity of judges. Thus, a judge cannot be held liable for any decision delivered on a case, except for committing crimes or irregularities. As regards acts which are not related to the exercise of professional duties, the judge shall bear legal liability in a general manner.

Likewise, the legal status of the Prosecutor's Office in Ukraine will be significantly amended. Thus, Chapter VII of the Constitution of Ukraine "Prosecutor's Office" is proposed to be fully removed. Presented in accordance with international and European standards, the provisions on the legal status of Prosecutor's Office will be included in Chapter VIII "Justice". In particular, some duties of the Prosecutor's Office have been removed as they were not in compliance with the European standards: to see to the observance of any individual and citizen's rights and freedoms; to see to the

\footnotetext{
2 Document CDL-AD (2015) 027 of 23 October 2015, available at tp://www.venice.coe.int/webforms/ documents/?pdf=CDL-AD(2015)027-e.

${ }^{3}$ The first five years, the so-called "probationary" period for judges.
}

CONSTITUTIONAL LAW REVIEW 


\section{Constitutional reform in Ukraine - a means of improving the judiciary}

observance of laws on these matters by the executive authorities, local governments and their officials ${ }^{4}$; to see to the observance of laws during the execution of judgments in criminal cases, as well as the application of other coercive measures on restriction of citizens' personal freedom.

As a result of the proposed amendments, the Prosecutor's Office will present the public prosecution in the courts; the supervision and the procedural direction of the pre-trial investigation; the settlement, according to the law of other problems that occur during criminal proceedings.

In accordance with the recommendations of the Venice Commission, the proposed changes distinguish the Constitutional Court of Ukraine as an independent authority and different from the courts of law. It is stated that the Constitutional Court of Ukraine decides on the constitutionality of Ukrainian laws and in the cases stipulated by law of other acts, the Court interprets the Constitution of Ukraine and under the Constitution of Ukraine it can exercise other duties. The Constitutional Court of Ukraine shall have no jurisdiction to interpret the laws of Ukraine, because this feature does not apply to constitutional courts or other similar authorities.

An important step in establishing the rule of law by strengthening the national system for the protection of human rights in line with modern practices of European countries is the introduction of the possibility of addressing an individual constitutional complaint, which means an appropriate enlargement of the powers of the Constitutional Court of Ukraine.

An important authority aimed at strengthening, developing, protecting the principles and values of constitutionalism, an effective constitutional means of solving social conflicts is justice, and, above all, constitutional justice. Legal supremacy of the Constitution and the direct effect of its provisions are not automatically applicable, i.e. it is not excluded that the rules and principles laid down in the country's basic law could be violated by the subjects of public relationships, both in the legislative area and in the law enforcement process. As a result, the creation of the preconditions of a possible conflict between the legal and the actual constitution may be possible and the implementation of relevant regulations can be questioned. To avoid such a crisis, the government creates a system and a mechanism for the legal protection of the Constitution.

As noted by M. Savcin, "depending on the weight to the legal or political means of ensuring the supremacy of the constitution, there are "easy» mechanisms and judicial mechanisms for the protection of any individual's fundamental rights and freedoms, which also define the political constitutionalism or the judicial (legal) one. If the first type of constitutionalism ensures the achievement of the principle of separation of

\footnotetext{
${ }^{4}$ The so-called "general monitoring".
}

CONSTITUTIONAL JURISDICTIONS 


\section{Oleksandr ŞCERBANIUK}

powers, the second one guarantees the achievement of any individual's rights and as a final result, the latter leads to the limitations of the arbitrary power" ${ }^{\prime 2}$.

The main role in forming the judicial constitutionalism is held by the Constitutional Court of Ukraine, which presents a manifestation of the legal constitutionalism and simultaneously it is a protection tool for the Constitution of Ukraine. Thus, characterizing the judicial constitutionalism according to the Constitution of Ukraine, A. Selivanov emphasis, as follows: "The expression «judicial constitutionalism» in the modern sense of the emergence of new fields of constitutional regulation is treated as a direct effect of the Constitution, which is complemented by legal positions of the Constitutional Court and of the Supreme Court of Ukraine. These authorities guarantee the human rights and freedoms and ensure the stability of constitutional order in the country"6. In this context, N.S. Bondar's suggestion is appropriate: "Without a constitutional complaint, not only the constitutional justice, but also, to some extent, the constitutionalism becomes selective, partial"7.

Judicial constitutionalism means that the initiation of the process of institutionalization of the legal provisions (verification of compliance with the Constitution) can be made not only by the public entities, but also by the individual, citizen, holder of rights and freedoms ${ }^{8}$.

The Constitution of Ukraine guarantees the appeal of every individual to the court of law in order to protect the violated rights and freedoms. The lack of the constitutional complaint concept diminishes the completeness of legal forms for the accomplishment of the right of defence by the court. This major deficiency causes the numerous applications of citizens to the European Court of Human Rights. The mechanism of legal and constitutional protection of fundamental rights and freedoms greatly improves the system of protection for individuals. In this context, the establishment of the constitutional complaint in Ukraine as a means to protect and guarantee any individual's human rights and freedoms is necessary and indispensable.

Within the science of constitutional law of Ukraine, the concept of constitutional complaint has been investigated for the first time by the judge of the Constitutional Court of Ukraine, M.P. Hultaj. The need for the introduction of the constitutional complaint concept in Ukraine was substantiated by P. Evgrafov, A. Selivanov, M. Teslenco. According to the research done by A. Selivanov, the constitutional complaint not only determines the direction of the trial development in which the

\footnotetext{
${ }^{5}$ Konstytucijne pravo zarubijnyx krajin. Tom. 1: Zahalna chastyna/pid red. d.ju.n., prof. N.V. Mishchynoji ta doc. V.O. Mixalova. Dnipropetrovsk: Serednjak T.K., 2014. - S. 293.

${ }^{6}$ A.O. Selivanov, Sudovyj konstytucionalizm u realijax suchasnoho rozuminnja Konstytuciji Ukrajiny, [Elektronnyj resurs] - Rejym dostupu: http://www.golos.com.ua/article/254819.

${ }^{7}$ N.S. Bondar, Sudebnyj konstytucyonalyzm v Rossyy v svete konstytucyonnoho pravosudyja. M.: Norma, Ynfra-M, 2011. - S. 115.

8 O. Pfersmann, Selektyvnoe pravovoe hosudarstvo y konstytucyonnaja jaloba//Konstytucyonnoe pravo: vostochnoevropejskoe obozrenye, 2003, no. 3 (44). - s. 175.
} 


\section{Constitutional reform in Ukraine - a means of improving the judiciary}

individual can exercise the inherent right under the Constitution, but it also ensures the compliance with the constitutional procedure by this person ${ }^{9}$.

According to some arbitrary opinions, the introduction of the constitutional complaint could results in the situation where the Constitutional Court of Ukraine would become a monopoly authority in the application of constitutional norms.

In Ukraine, the Bill no. 3524 of 25 November 2015 on amending the Constitution of Ukraine in the area of justice provides for the introduction of any individual's right to bring a constitutional complaint before the Constitutional Court of Ukraine. In accordance with Article 151-1 of this bill, the Constitutional Court of Ukraine decides on the compliance of Ukrainian laws with the Constitution (constitutionality) based on the constitutional complaint of an individual who believes that the law which has been applied during the adoption of the final decision in its case infringes the Constitution of Ukraine. The constitutional complaint can be filed only after exhausting all domestic remedies ${ }^{10}$.

Based on the analysis of Article 151-1 of the Draft amendments to the Constitution of Ukraine on justice, the subject matter of an appeal may be the law of Ukraine. This involves the introduction of the normative type of constitutional complaint. According to the ideas of M.P. Hultaj, the normative constitutional complaint, which justifies the limitation of the number of appeals to the Constitutional Court, releases easily the authority of constitutional review and ensures an appropriate and full separation of constitutional jurisdiction and of jurisdiction of other courts of law ${ }^{11}$.

The European Commission for Democracy through Law of the Council of Europe (Venice Commission) in its report "On direct access to constitutional justice" recommended that the Constitutional Court of Ukraine shall express itself only on the constitutionality of legal regulations, whereas the monitoring of the legality of individual acts shall be exercised by the courts of common law.

The introduction of the constitutional complaint requires a theoretical analysis of its elements: the subject matter, the form, individuals who have the right to initiate, the terms used to notify the Constitutional Court, the eligibility criteria and the procedures for examining the constitutional complaint by the constitutional authority. Thus, the constitutional complaint contains the petitioner's application for the repeal of the law which infringes the Constitution of Ukraine, namely a particular substantive requirement which the individual brings before the court of law. The constitutional complaint may be filed only on the constitutionality of the law. The constitutional complaint filed against the regulations under the law regarding an individual's constitutional rights shall not be allowed.

\footnotetext{
${ }_{9}^{9}$ A.O. Selivanov, Konstytucijna skarha - vajlyva oznaka demokratyzaciji derjavy, Holos Ukrajiny no. 236 (6240). 15 hrudnja 2015 r. - s. 4.

10 Proekt Zakonu pro vnesennja zmin do Konstytuciji Ukrajiny v chastyni pravosuddja vid 25 lystopada 2015 r. no. 3524, [Elektronnyj resurs] - Rejym dostupu: http://constitution.gov.ua/work/item/id/13.

11 M.P. Hultaj, Povna chy normatyvna konstytucijna skarha: poshuk nacionalnoji modeli, Visnyk Nacionalnoji Akademiji pravovyx nauk Ukrajiny, 2013, no. 1(72) - S. 30.
}

CONSTITUTIONAL JURISDICTIONS 


\section{Oleksandr ŞCERBANIUK}

Another element of the constitutional complaint is its grounds, namely those factual circumstances and the regulations of the law according to which the applicant motivates her/his complaints. An individual may appeal to the Constitutional Court only if all domestic remedies have been exhausted. That individual must provide a copy of an official document confirming that a final decision in her/his case was delivered based on a law which violates the Constitution of Ukraine.

The constitutional complaint shall be accepted for examination if certain criteria on its form and content are met. The requirements of the constitutional complaint should be clearly defined in the Law of Ukraine regarding the Constitutional Court of Ukraine. Otherwise, the constitutional complaint shall be filed in writing and contain the following: the name of the individual who addresses the complaint and the name of her/his representative; the name of the authority, the legislative act which is disputed; the revisions of the legislative act. The legislative regulation of the term specified for the introduction of the constitutional complaint shall be equally important. According to the importance of the issues addressed in the constitutional complaint and which require to be settled by the constitutional justice, this aspect requires further analysis, since the terms of appeal in foreign countries vary from fifteen days to the appeal at any time. Likewise, the establishment of the procedural rights and obligations of the parties involved in the constitutional procedure shall be equally important.

As a result of numerous discussions on the need for the revision of the Constitution of Ukraine on 2 June 2016, Law no. 1401-VIII on constitutional amendments to justice was adopted, which shall take effect on 30 September 2016. Simultaneously, it was adopted the Law on judiciary and status of judges, which defines and guarantees the right of each individual to a fair trial and provides the judicial reform and the status of judges in line with European standards. Likewise, the revision of the Constitution of Ukraine requires the improvement of the legislative regulation regarding the duties and the powers of the Constitutional Court of Ukraine. For this purpose, on 17 June 2016, the Constitutional Court of Ukraine held an international scientific-practical seminar where it was discussed the Draft law regarding the Constitutional Court of Ukraine and the principles of constitutional justice.

Thus, the proposed constitutional amendments meet all European and international standards. They will ensure the functioning of the judiciary specific to the rule of law and guarantee any individual the right to a fair trial before an independent and impartial court.

The Constitutional Court of Ukraine became the public legal mechanism that will ensure a balance of power and freedom to the public and private interests. The individual's right to act as applicant before the Constitutional Court of Ukraine belongs to any individual and citizens' inalienable rights. They must determine the content and effectiveness of laws in a state, being one of the fundamental values of the constitutional order in Ukraine. Without their observance and providing state protection, the true democracy cannot be established. The establishment and the functioning of the rule of law are impossible. 